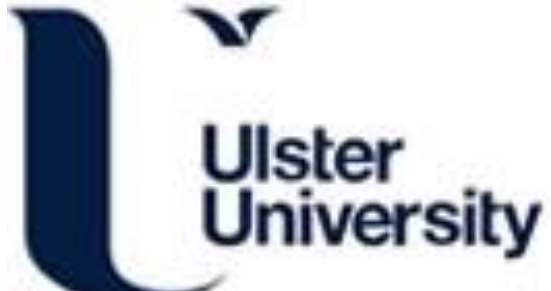

\section{Health informatics education: balancing academic achievement and professional development}

McCullagh, PJ., \& Finlay, D. (2010). Health informatics education: balancing academic achievement and professional development. Swiss Medical Informatics, 70, 18-21.

Link to publication record in Ulster University Research Portal

\section{Published in:}

Swiss Medical Informatics

Publication Status:

Published (in print/issue): 01/01/2010

\section{Document Version}

Publisher's PDF, also known as Version of record

\section{General rights}

Copyright for the publications made accessible via Ulster University's Research Portal is retained by the author(s) and / or other copyright owners and it is a condition of accessing these publications that users recognise and abide by the legal requirements associated with these rights.

\section{Take down policy}

The Research Portal is Ulster University's institutional repository that provides access to Ulster's research outputs. Every effort has been made to ensure that content in the Research Portal does not infringe any person's rights, or applicable UK laws. If you discover content in the Research Portal that you believe breaches copyright or violates any law, please contact pure-support@ulster.ac.uk. 


\title{
Health informatics education: balancing academic achievement and professional development
}

\author{
Paul J. McCullagh, Dewar D. Finlay \\ School of Computing and Mathematics, Faculty of Computing and Engineering, University of Ulster at Jordanstown, Newtownabbey, Co. Antrim, \\ Northern Ireland, United Kingdom
}

\begin{abstract}
Summary
This paper addresses experiences with the teaching of health informatics, within the Computer Science discipline, in the United Kingdom. A postgraduate course was designed, and targeted at serving informatics professionals working full-time in the National Health Service, in Northern Ireland. Many informatics health service positions do not require a formal Informatics background, and as we strive for professionalism in this discipline, a qualification is an important asset. The syllabus complements the participant's experience and work-based achievement, and provides insight into emerging technologies associated with the "connected health" paradigm. The course was designed with involvement from the Health and Social Care Training Group, and delivered in a flexible manner to facilitate uptake and participation. It provides concurrent qualifications: a postgraduate qualification accredited by the University of Ulster and a professional Certificate validated by a professional body comprising experienced health informatics professionals. Our experiences have shown that it is important to strike a balance as delivering both qualifications simultaneously puts significant demands upon part-time students.
\end{abstract}

\section{Introduction}

Lord Darzi in his 60th year review [1] sets out how the United Kingdom's National Health Service (NHS) faces the following 21st century challenges: rising expectations; demand driven by changing demographics; the continuing development of the "information society"; advances in treatments; the changing nature of disease; and changing expectations of the health workplace. He concluded that the NHS should anticipate and respond to these challenges. Recommendations of particular interest to higher education are:

"A clear focus on improving the quality of NHS education and training. The system will be reformed in partnership with the professions."

In Northern Ireland (NI), on 22 January 2008, Health Min-

\footnotetext{
1 It is estimated that approximately 30,000 service staff will become direct users of the new IT systems and services being introduced by HSC ICT Strategy. Untrained Users Cost More to Support than Trained Users - Leslie Fiery, Bill Kirwin - Gartner Research, 14 March 2006, ID No. G00138330.
}

ister Michael McGimpsey launched the European Centre for Connected Health [2]. He announced an investment package by 2011 of $£ 22 \mathrm{~m}$ annually, to remotely monitor 5000 patients in disease areas such as heart failure, pulmonary disease and diabetes.

Health Informatics (HI) and in particular, well educated and trained HI specialists can respond to the challenges identified by Darzi and McGimpsey. HI lies at the intersection of informatics and the health and social care disciplines. It equips healthcare professionals with better information handling and interpretation skills. It may be defined as:

"The knowledge, skills and tools which enable information to be collected, managed, used and shared to support the delivery of healthcare and to promote health" [3].

The need for a course has been confirmed by Health and Social Care (HSC) ICT training group, who have encouraged the development and facilitate participation by employees $^{1}$, by offering financial support. The course is designed to provide education and training for the ICT "specialists", who will become the leaders of the ICT strategy. Education, training and development are key to the understanding and skills that enable staff to utilise ICT effectively to the benefit of patients and clients. It is widely acknowledged that both health and social care information is not always used and managed so as to provide the most effective care. There are gaps in current levels of awareness, attitudes, knowledge and skills about information management amongst HSC staff. The case for enhancing the learning agenda has been strengthened by HSC ICT Strategy [4]. In September 2007, the largest NI survey of Healthcare Professional in relation to ICT was published [5]. From a total population of 22130 staff, 3687 (17\%) people were surveyed and 1060 (29\%) questionnaires were returned. Staff had a positive perception to ICT, with $81.2 \%$ using a computer at home and work. However, only $44 \%$ of all respondents had formal training. Only $5 \%$ indicated

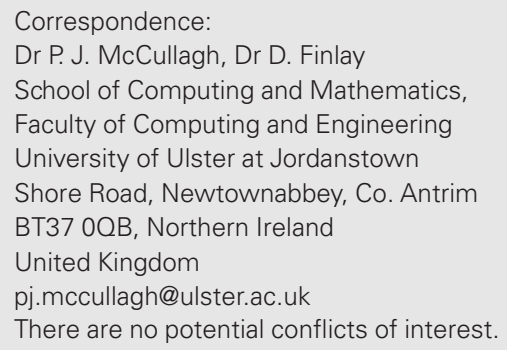


that they could design a Web page. There was strong support for ICT education for health professionals $(93 \%, \mathrm{~N}=$ 997). The conclusions of the study included support for a two-tier approach with multiprofessional training concentrating on basic training for all staff and uniprofessional training specific to the needs of particular professional groups or specialities. A further recommendation was to "maximise online learning strategies for delivery content".

\section{Northern Ireland Health Informatics}

In Northern Ireland, the Health+Care Number (HCN) Project provides an equivalent to the NHS number, potentially linking the various ICT systems. A Primary Care programme covers the ICT and communications interfaces within HSC for the family practitioners, Pharmacy, Dentistry and Optometrists. An Emergency Care Record project has been implemented in some regions. A Clinical Oncology Information System permits care professionals in all Cancer Units to access patient records for chemotherapy patients. A Cervical Screening and Cellular Pathology system will replace legacy systems in the main hospitals. An Electronic Prescribing and Eligibility System (EPES) is evaluating a counter fraud unit. A Medicines Management Technology project supports prescribing support in hospitals.

A Community Information System (CIS) is planned and technology for managing radiology information and picture archiving and communications images (RIS/PACS) is being rolled out [6]. A theatre management system is running in Altnagelvin, Craigavon, South Tyrone and Mater hospitals. Implementation is underway in other hospitals.

\section{Course planning and mode of delivery}

A postgraduate course in HI was planned in close collaboration with HSC ICT Training Group [7], which has responsibility for ICT training in the health service in NI. The programme met the aim of widening participation, to a well motivated group of professionals. The course is delivered by blended learning, providing a learning opportunity to this cohort, which would be impractical without such flexibility, due to the demands of the workplace [8]. It caters for part-time students by employing web-based for deliv- ery, enabling distance and asynchronous learning opportunities complemented by traditional delivery and student support. It utilises a significant body of research expertise in areas such as requirements analysis, signal and image processing and data mining. It also benefits from applied research and knowledge transfer projects in areas such as smart homes, ambient assisted living, medication management, and selfmanagement of chronic disease.

\section{Structure of the course}

This course is studied part-time. Delivery is by blended learning, with face-to-face sessions (up to 12 hours per module) as appropriate. Delivery is flexible, normally enabling a student to select one or two modules per semester. For a student wishing to complete the course in the shortest time, it should normally be possible to complete the award in four semesters, within a two-year period. For a student adopting a slower track approach, the course should normally be completed within four years to ensure currency. The course comprises eight taught modules, each worth 15 credit points. For MSc, a research study project worth 60 credit points is taken as the final module. The project is related to HI, the student's background and interest. A schedule which permits the diploma to be obtained in two calendar years is given in table 1 . The MSc will take an additional year.

Table 2 illustrates the course statistics, to date. The target is for 20 students per year, with a programme duration of at least five years, providing $100 \mathrm{HI}$ specialists in Northern Ireland. In year 1 of the programme, delivery started with one module per semester for a slow start-up. This provided good retention statistics (16/20). However, for year 2 entry (Sept 2009), the picture was not as promising. This can be attributed to delivering 2 modules per semester plus the professional certificate, which has caused $7 / 19$ students to defer, and two students to drop out. The dilemma is to provide such a course in a reasonable time frame but to incorporate the professional training and accreditation.

\section{The learning environment}

The course uses Blackboard's WebCT Virtual Learning Environment (VLE). Students are provided with reading material, but must engage with the tutor and each other via

\section{Table 1}

Organisation of modules.

\begin{tabular}{|c|c|c|c|}
\hline & Semester 1 & Semester 2 & Award \\
\hline \multirow[t]{2}{*}{ Year 1} & Electronic healthcare & $\begin{array}{l}\text { Information in health and social care } \\
\text { management }\end{array}$ & \\
\hline & $\begin{array}{l}\text { Analysing and presenting data and } \\
\text { information }\end{array}$ & Emerging healthcare technologies & Postgraduate Certificate \\
\hline \multirow[t]{2}{*}{ Year 2} & Electronic care records & $\begin{array}{l}\text { Decision support } \\
\text { systems }\end{array}$ & \\
\hline & $\begin{array}{l}\text { Electronic communication in } \\
\text { health and social care }\end{array}$ & Research methods & Postgraduate Diploma \\
\hline Year 3 & Research study & Research study (dissertation paper) & MSc \\
\hline
\end{tabular}


Table 2

Course statistics.

\begin{tabular}{lllllll} 
Entry & Enrolled & $\begin{array}{l}\text { Postgraduate } \\
\text { certificate }\end{array}$ & $\begin{array}{l}\text { Professional } \\
\text { certificate }\end{array}$ & $\begin{array}{l}\text { Deferred } \\
\text { course }\end{array}$ & $\begin{array}{l}\text { Left course } \\
\text { Recommence } \\
\text { studies }\end{array}$ \\
\hline Jan. 2008 & 16 & 12 & 12 & 2 & 2 & 0 \\
\hline Sept. 2008 & 4 & 4 & 4 & 0 & 2 & 3 \\
Sept. 2009 & 19 & 10 & 10 & 7 & 0 & \\
Sept. 2010 & 17 & - & - & 2 & & \\
\hline
\end{tabular}

group work (chat, discussions, and assessments). The VLE facilitates participation from all parts of NI, and the student cohort reflects this. There are however 3-4 face-to-face sessions per semester, which supports the VLE delivery. Consider the Electronic Healthcare module, addressing postgraduate objectives which include: design and modelling of information systems and evidence-based research on an HI topic of interest and relevance. The profession certificate for this module requires the completion of a personalised portfolio. This comprises two major themes:

- The role of Informatics in the provision of health and social care services;

- how an organisation uses Information Management and Technology (IM\&T) to support the delivery of care.

These modules are broken down further into learning objectives ("LO") as shown in table 3, and a further sublevel (not shown). Modules are assessed by an Internal assessor ("Int.", the course tutor), who provides feedback and support, and an External verifier (“Ext.”), who accepts the portfolio and recommends accreditation by a board of HI professionals in NI. Dates of completion are verified. These LOs have been updated since the course started to reflect the specific requirements of the NHS in NI (revision July 2010).

Table 3

Learning outcomes for professional certificate (Modules A + G).

\section{Discussion and conclusion}

Changes in the health ICT systems have created needs for new learning opportunities and skills to enable the workforce to gain the competences needed to cope with the requirements of these new modes of working and communicating. Educational institutions are tasked with the challenge of providing learning and skills to assist the transformation from inflexible traditional methods of learning to more flexible modes of delivery and support. As the healthcare industry contains many vocational professions, there has been a view in society that workers do not achieve the same rewards as in the commercial sector. Enhanced training and education and the move to profession recognition for ICT expertise can address this issue. There is of course a secondary benefit, enhancement of the quality of healthcare delivery which supports the most disadvantaged members of society.

A Health Informatics Review [9] was commissioned by the NHS Chief Executive and the Department of Health Permanent Secretary to assess the supply of, and demand for, information across the NHS and social care; ensure that the framework for the NHS Care Records Service and the Secondary Uses Service (SUS) is in line with policy; address governance of informatics within the NHS.

\begin{tabular}{ll} 
Lo & Requirement \\
A1 & $\begin{array}{l}\text { Document the evolution of health and social care in Northern Ireland. } \\
\text { A2 } \\
\text { of health and social care in Northern Ireland. }\end{array}$ \\
\hline A3 & $\begin{array}{l}\text { Demonstrate how your role contributes to the job of meeting the health } \\
\text { and/or social care needs of patients/clients. }\end{array}$ \\
\hline A4 & $\begin{array}{l}\text { Identify what performance and strategic information is considered important } \\
\text { in your part of the organisation. }\end{array}$ \\
\hline G1 & Discuss the use of IM\&T in NI H\&SC. \\
G2 & Summarise the sources and uses of H\&SC data and information. \\
G3 & Discuss the importance of the relationship between IT and people in NI H\&SC. \\
G4 & $\begin{array}{l}\text { Demonstrate an understanding of the IM\&T links between your department } \\
\text { and two others in the delivery of H\&SC. }\end{array}$
\end{tabular}


The course, discussed in this document, is intended for an HI specialist, with a sound knowledge of CS principles. The HI specialist should have an understanding of core computing concepts, supplemented by knowledge of specialist health information systems, clinical terminology, health nomenclature, health standards, ethics and governance and the role of decision support in healthcare. Due to the complexities of HI, the specialist should have core HI skills and an emphasis on the local health system organisation. The course benefits from applied research and knowledge transfer projects in areas such as smart homes, ambient assisted living, medication management, and self-management of chronic disease. The course has taken in four cohorts, although the first two cohorts (Jan. 2008 / Sept. 2008) may be considered really one, as it allowed for staggered student entry and development of modules for providers.

The students have found the course demanding, and it could be that two modules per semester requires too much time commitment for the busy part-time student. The postgraduate course provides intellectual challenge, and exposure to emerging technologies relevant to "connected health". Performance in assessments has been to a good standard, as verified by the external examiner.

However, there has been a relatively high attrition rate for the second cohort (deferral mainly but some drop out). Discussions with students indicate that the demands of the professional portfolio provide significant additional workload. Although there is intentional overlap in topics between postgraduate and professional threads of the pedagogy, the necessity to address and document all learning outcomes in a comprehensive manner provides a significant additional time burden. Of course there is no "template" answer, as the portfolio has a significant element of personalisation. Solving this dilemma of concurrently delivering postgraduate challenge with professional verification will ultimately determine the success of the initiative. One major benefit of the course has been the establishment of a HI "community" comprising many grades and roles (consultants, junior doctors, network managers, administrators) with the NI HI sector, due to team work elements of the course. In addition to the development of the course, HI has now emerged as a pathway within our core BSc Computing Science HI, allowing students to select options in "Health Informatics", "Emerging Healthcare Technology" and a health related project. This is in its first year of delivery, but has proved very popular with the student cohort. Indeed these modules are more popular with computing students than more traditional CS options.

\section{References}

1 Darzi Lord. NHS Next Stage Review, High Quality Care For All, 30 Jun 2008, www.ournhs.nhs.uk/, accessed Feb 2010.

2 McGimpsey M. Ministerial Speech, European Centre for Connected Health. www.eu-cch.org/index.htm, accessed Feb 2010

3 Making Information Count. Department of Health, 2002.

4 The HSC Information \& Communications Technology Strategy 20032010.

5 Sinclair M, McGlade K, Comac P, Kelly B, Brown H, Hatamleh R, Stockdale J. Knowledge, Skill and Attitude of NI FHSSPS Healthcare Professionals towards Information and Communication Technology: Report of a Northern Ireland Survey, ISBN 13 978-1-85923-223-1, Sept 07.

6 EHealth Europe (Oct 2008), www.ehealtheurope.net/news/4207/northern_ireland_picks_sectra_for_ris/pacs, Accessd Feb 2010.

7 HSC ICT Training Group, www.beeches-mc.co.uk/, accessed Feb 2010.

8 Alexander S, Kernohan G, McCullagh P. Self Directed and Lifelong Learning, in Global Health Informatics Education Studies in Health Technology and Informatics 109 (Edited by E.J.S. Hovenga, J. Mantas), 2004.

9 Keogh B. Health Informatics Review, Department of Health, July 2008. 